\title{
Reducing Cheating Chances by Involving Critical Thinking Skills within the Assessments: Students' Perspective
}

\author{
Nida Husna HR \\ \{nida.husna@uinjkt.ac.id\} \\ UIN Syarif Hidayatullah Jakarta, Indonesia
}

\begin{abstract}
Cheating was a serious problem that was done consciously by the students in working the assessments even though they understand the consequences. Therefore, creating a specific assessment as a tool to monitor their work that could prevent them from cheating was seriously needed. Applying critical thinking skills as the requirement within the assignment was chosen to reduce the cheating possibility. This study was conducted to find out the students' perspective about the integration of the CT skills in the assessments when doing Extensive Reading program.The result of the study have shown that most of the students agreethat by adding CT skills as part of the requirement, they prefer to rely on themselves when working on their assessment. According to them, it was no use to cheat because the CT skills required them explore their own way of thinking.
\end{abstract}

Keywords: cheating, critical thinking, assessment.

\section{Introduction}

The studies that show that extensive reading influenced students' ability both in language skills and language components had been done worldwide.Extensive reading has been proven to develop students' foreign language skills where the access to English was very limited, or when the students were less motivated [1][2][3]. An appropriate approachwould be needed to reduce the anxiety from reading many materials, which in the end would make the students could feel more enjoyment during the process [1]. Extensive reading improved students' reading comprehension [4], reading speed and comprehension [5], English general skills [6][7][8], vocabulary [9][10][11], reading attitude [3], writing [12][13] and many others.

Even though ER was already implemented worldwide, it was still at its early stage in Asia. The condition of ER in Indonesian classroom was roughly at the same stage Japan and Korea were some 10-15 years ago [14]. There were several specific reasons why it was not easy to implement an extensive reading program in formal Indonesian classrooms. One of the reasons was that, in conducting ER, the teachers were rquired to think beyond the ordinary languagefocused, teacher-controlled classroom which prepared students for high-stake exams. However, the condition should be different when it was to be conducted in college or university level because of the different policy and outcome. University level of education was also benefit from the degree of freedom in deciding the curriculum and syllabus, because the difference in graduate expectations. 
Among those which have implemented ER program in university level was UIN Jakarta. It was almost a decade that English Education Department in Faculty of Educational Sciences in UIN Jakarta had conducted ER program. Of course, there were problems in first years when it was conducted. Providing proper materials would be one of the obstacles, because there was no specific funding provided by the institution to buy the novels while the expensive price of the novels added another problem. In addition, supervising of the circulation of the novels could not be managed by the teachers themselves, they would need help from the students. Therefore, this program should be well arranged to meet the objective and experienced many trial and error processes, including in preparing the asessement.Common understanding stated that there was no assignment follow ER activities, if there was, it would be a little. However, since the program was part part of the curriculum, it should be graded. Therefore, some asessments should be designed so the students' work can be scored.

In educational field, assessment was not merely part of grading system, further, it could play important part of instruction to support and enhance teaching learning process [15]. Assessment has also been considered to harm many of the students if it was not properly planned and designed [15][16]. The harmfulness of assessment usually as the result of the failure in balancing the standardized test and the classroom assignment [16]. Meanwhile, in higher educational level, the assessment should be further well prepared to equip the students with the ability to keep learning sustainably within the society [17].

The assessment that was applied in this program was hopefully can be utilised to accelarated students' learning [18] and empower the students to become self-regulated learners [19]. In designing it, the most challenging part was how to create an assessment that could help the students to retell the story without losing the chance to express themselves, including to maximize the chance to practice their language skills. Another important challenge was how to minimize the cheating probability among the students. Furthermore, since the reading materials would be very various, it was really needed to create an asessment that can be used to any of those type of reading to help the teachers reduce the burden in doing the correction and scoring.

During the process of designing the asssessment, it was found that the most difficult part in assessment processwas the attempt to minimize the cheating probability. Cheating was defined by King, Guyete and Piotrowski (2009) "as a transgression against academic integrity which entails taking an unfair advantage that results in a misrepresentation of a student's ability and grasp of knowledge" (p.4) [20]. While Trenholm (2007) said that cheating was also "referred to as academic dishonesty" (p. 284) [21]. Another study also stated that cheating was defined as an activity that going against university policy, benefiting from someone else's work and not using our own brain to get an unearned grade[22].

Due to the imbalance number of students and the materials provided, repetition was unavoidable and so was cheating. Some still tried to work on reading seriously even though they read the same materials, while many others prefered the easy way out by copying others' work. Therefore, after years of trial, critical thinking skill then was applied as an attempt to support the evidence of students' work independency.

The addition of critical thinking ability in the assessment was then become one of the main parts in deciding whether the students really read or not even though of course that would not be enough. Some other strategies were also applied to help the students fulfill the requirement of the program while critical thinking was almost cannot be separated in the process of each.

The consideration in adding critical thinking was actually came from the concern of students' ability in giving questions when they have discussions in paper presentation sessions. Of course less in paying attention was also part of their ability in creating proper 
questions. However, the attempt to help the students' ability in using those skills in critical thinking should be conducted, because it was very important for them especially to work on their assignment in their next level of subjects, and to help them react better in facing wide range of issues in their real world.

Generally, critical thinking skills could be summarized as the ability to find any possibilities when solving a problem, considering different perspectives and being able to see the other's argument as part of an alternative contribution, or conclusions, on a specific topic [23].The ability to use critical thinking would help the students to avoid making mistakes repeatedly and stating bad advice or creating unfavorable decisions [24]. However it needed a hard work to develop it and to make it as habit. In practice, the students should be disciplined in guiding themselves so they could practice to give reasons as the high part of the critical thinking process [25]. It was also stated that this practice would help the students to have rational, reasonable, and emphatic live, as well as develop their intellectual virtues. Therefore, adding some skills of critical thinking would not only help the students avoiding to cheat each other, but also help them to develop the skills that could help them to avoid prejudices and biases as well as narrow ideas when facing complex issues around them.

Therefore, it was needed to conduct a study that could give the evidence that the implementation of CT skills in assessments in this extensive reading program could reduce the cheating chances. As the initial step, this study would focus on finding the students' perception about the assessment itself as the foundation for further research.

\section{Methodology}

This study was a preliminary step in investigating the use of critical thinking skills to reduce cheating probability in the assessment. Since this study was aimed to see the students perspectives about the implementation of CT skills in ER assessment toward cheating probability, qualitative method would be applied.

The assessments in Extensive Reading program in the English Education Department (EED) were integrated with other skills to get the maximum benefit of ER. All language skills were used as part of ER activities, and within those skills, CT played an important part of their effort in doing the ER projects and assessment. Each type of the reading material given in ER had a different type of assessment.

The research was conducted in an English Education Department (EED) at Faculty of Educational Sciences, UIN Jakarta. The students at EED were at an advanced level of English proficiency and they had a specific objective: to become future English teachers. 30research participants, from 18 to 21 years age range, from three classes in their fourth semester of undergraduate study were involved. These participants were enrolled in an ER course; this number of participants was 37 per cent of a total of 82 students taking the course at that time. They were the ones who took the pre- and post-reading tests. 
A questionnaire was used as an instrument to gather the information from the students. It was given to the students through google form. There were seven questions asking the students' understanding and perspective toward the assessment given in the questionnaire.

\section{Findings and discussion}

\subsection{Findings}

There were seven questions that were related to the assessment that were asked to students in the questionnaire. The first question was about whether or not the students know that the material (novels) that they read was also read by other students previously. From 30 students, five students stated that they did not know, while the rest $(83,3 \%)$ believed that they knew. However, based on the next question, even though they knew that other students have ever read those materials, and they had the chances to see those work, $90 \%$ of the students still read the same materials anyway, while the rest $10 \%$ preferred no to read them and find other materials.

Even though there were wide chances to refer to the previous works, there were only four students $(13,3 \%)$ that would refer their work to those previous ones. The other $86,7 \%$ preferred not to do it with various reasons. Most of the responses stated that they believe in their own ability. According to them, by referring their work with the previous ones would show that they were not confidence with their own ability, and they believed it was a lost to gain the most benefit of the course. Some others stated that they did not need to refer to the previous work because they believed that they understand how to do the assessment properly and they preferred to believe in their own work rather than being influenced by others. According to them, people would have different understanding and perspectives toward the story, and they did not want their judgment to be influenced by others'.

$100 \%$ students stated that they understand perfectly about how to do the assessment even though there was still one student who did not understand why the assessments were arranged that way. The $96,7 \%$ students claimed that they understood the reason why the assessment had critical thinking skills component as the main requirement.

In the last question, there were 12 students from 30 who stated that there was no chance to cheat with the way the assessment was arranged. The rest 18 students believed that the probability was of course exist, however, it would be difficult to do it because the critical thinking factor (reasoning) that was the main requirement would more or less prevent them to cheat. On top of that, even though there was a chance, many of them preferred not to take it for the sake of achieving greater objective, that was acquiring the language skills through regular and supervised practiced. Therefore, they did not think that they need to cheat because they really wanted to accomplished the aim of the course and felt the challenges themselves.

\subsection{Discussion}

There were three elements (fraud triangle) which were considered as the reason of cheating existence: incentive/pressure, opportunity, and rationalization/attitude [26]. When it was related to academic, those who saw the incentive/pressure elementwould focus on earning a good grade or better score (meanwhile the opportunity manifested itself in an environment when it was believed that no one was watching). For those who were in the element of rationalization/attitude became more prevalent and excusable when there was a perception that "everyone is doing it anyway." The "examination" environment was a potential condition to create the fraud triangle. However, there was of course a probability that the opportunity to 
cheat was minimized when the faculty member was present during the examination, and required that all notes, electronic devices, and other materials be put away, and carefully watched the students.

Avoiding cheating totally would be hard to do, especially in the era where technology was very helpful, including smoothing the cheating process [22]. Meanwhile, the law enforcement when the student was caught cheating was difficult to implement due to many reasons, including the non existence of uniformity among the instructor [27]. The students who preferred to work on their task by relying on their own ability and not to engage in cheating were assumed to have a higher moral compass for their positive behavior [28]. Meanwhile, some of the reasons for those who did it included the desire to help others, procrastination, the need to pass the class, course difficulties, having an assumption that "it didn't matter if I cheat", or thinking that cheating was easy anyway [29][30].

Even though it was still debatable, indeed the responsibility for reducing cheating lies with both students and academic institutions. Reducing it, was also considered as one of the most important components to promoting academic integrity on college campuses and was to ensure that faculty and students understand the values and expectations of the institution [31]. What made it more difficult to overcome was that most of the time the faculty preferred to handle cases individually [32][33]. Some of the reasons for such action were because the incidents of cheating were difficult to prove, there was a lack of knowledge regarding the policies of the institution, or the institution had an organizational culture that discouraged faculty from reporting such cases.

It should be acknowledged that an individual instructor was suggested to be able to minimize cheating in their class [31]. For example, there was a need some practical pedagogical methods that can be applied to help students avoid the pressure of cheating especially during the exam. Therefore, it was important to carefully planned when designing the exam and assessment. Implementing some specific requirement that was considered to minimize the students' pressure should be put into action. By knowing some noble behavior from the ability of thinking critically, the pressure to cheat would be eliminated by the students themselves [34][35]. The skills in CT required the students to get used to broaden their perspectives as well as honor their own opinions by keep practicing the capability in analysing and reasoning. Having well understanding about the objectives of the assessment and motivating them to work with integrity would hopefully become one of the ways to reduce cheating.

\section{Conclusion}

As an initial step, it could be concluded that the implementation CT as one of the requirements in the assessment was helpful enough to avoid cheating and repetition. Even though the chance was there, due to the nature of assessment and positive behavior of the students, cheating behavior was unlikely to become the choice in this program. However, of course further study would be needed to claim that CT was useful in reducing cheating activity. The availabilty of evidence such as the students' work would strengthen the result of the study.

\section{References}


[1] Ro, E.: “A case study of extensive reading with an unmotivated L2 reader". Reading in a Foreign Language, Vol. 25, No. 2, pp. 213-233, 2013. Diambil kembali dari http://nflrc.hawaii.edu/rfl

[2] Safaeiaa, L. A., \& Bulcab, M.: "Extensive reading and creative practices". Procedia Social and Behavioral Sciences, Vol. 70, pp. 592 - 597, 2013.

[3] Yamashita, J. "Effects of extensive reading on reading attitudes in a foreign language". Reading in a Foreign Language, Vol. 25 (2), pp. 248-263, 2013.

[4] Tamrackitkun, K.: "Extensive reading: An empirical study of its effects on EFL Thai students' reading comprehension, reading fluency and attitudes". PhD diss. University of Salford, 2010.

[5] Bell, T.: "Extensive reading: Speed and comprehension". The Reading Matrix, Vol. 1, No. 1, 2001. Taken from http://www.readingmatrix.com/articles/bell/

[6] Robb, T. N., \& Susser, B.: "Extensive reading vs skills building in an EFL context". Reading in a foreign language, Vol. 5, No. 2, pp. 239-251, 1989.

[7] Yamashita, J. "Extensive reading and development of different aspects of L2 proficiency". System, Vol. 36, pp. 661-672, 2008.

[8] Macalister, J.: "Integrating extensive reading into an English for academic purposes program". The Reading Matrix, Vol. 8, No. 1, pp. 23-34, 2008.

[9] Nation, P.: "Principles guiding vocabulary learning through extensive reading". Reading in a foreign language, Vol. 27, No. 1, pp. 136-145, 2015.

[10] Cho, K.-S., \& Krashen, S. D.: "Acquisition of vocabulary from the Sweet Valley Kids series: Adult ESL acquisition”. Journal of Reading, Vol. 37, No. 8, pp. 662-667, 1994.

[11] Coady, J.: "L2 vocabulary acquisition through extensive reading”. Dalam J. Coady, \& T. Huckin, Second language vocabulary acquisition: A rationale for pedagogy, (Cambridge: Cambridge University Press), 1997, pp. 225-237.

[12] Nation, I.S.P., Newton, J. "Teaching ESL/EFL Listening and Speaking $1{ }^{\text {st }}$ Edition, Routledge, 2008.

[13] Lyutaya, T.: "Reading logs: Integrating extensive reading with writing tasks". English Teaching Forum, Vol. 1, pp. 26-34, 2011.

[14] Waring, R., \& Husna, N.: "Expectation and experiences of Indonesian teachers who have, and have not done extensive reading”. TEFLIN, Vol. 30, No. 2, pp. 153-170, 2019.

[15] Shepard, L. A.: "The role of assessment in a learning culture". Educational Researcher, Vol. 29, No. 7, pp. 4-14, October 2000.

[16] Stiggins, R. J.: “Assessment crisis: The absence of assessment for learning". Phi Delta Kappan, Vol. 83, No. 10, pp. 758-765, 2002.

[17] Boud, D.: "Sustainable assessment: rethinking assessment for the learning society". Studies in Continuing Education, Vol. 22, No. 2, pp. 151-167, doi:10.1080/713695728, 2000.

[18] Sadler, D. R.: "Formative assessment: Revisiting the territory". Assessment in education: principles, policy \& practice, Vol. 5, No. 1, pp. 77-84, 1998.

[19] Nicol, D. J., \& Macfarlane-Dick, D.: "Formative assessment and self-regulated learning: A model and seven principles of good feedback practice". Studies in higher education, Vol. 31, No. 2, pp. 199-218, 2006.

[20] King, C. G., Guyette Jr, R. W., \& Piotrowski, C.: "Online exams and cheating: An empirical analysis of business students' views:. Journal of Educators Online, Vol. 6 , No. 1, pp. 1-11, 2009. 
[21] Trenholm, S.: "A review of cheating in fully asynchronous online courses: A math or fact-based course perspective". Journal of Educational Technology Systems, Vol. 35, No. 3, pp. 281-300, 2007.

[22] Raines, D. A., Ricci, P., Brown, S. L., Eggenberger, T., Hindle, T., \& Schiff, M.: "Cheating in online courses: The student definition". Journal of Effective Teaching, Vol. 11, No. 1, pp. 80-89, 2011.

[23] Jimenez, G., Haydee, L., Rosales, O., \& Soraya, E. A.: "Extensive reading: A meaningful to develop critical thinking in ESL students at a university level". School of Arts and Science, Foreign Language Department, El Salvador: University of El Salvador, 2010 .

[24] Press, T. C.: "Risks-Associated-with-Weak-Critical-Thinkers". (The California Academic Press LLC), December 2018. Taken from www.insightassessment.com: https://www.insightassessment.com/Uses/Risks-Associated-with-Weak-CriticalThinkers

[25] Elder, L.: "Defining critical thinking". (Foundation for Critical Thinking), September 2007, Dipetik dari www.criticalthinking.org: https://www.criticalthinking.org/pages/defining-critical-thinking/766 pada December $\underline{2018 .}$

[26] Ramos, M.: “Auditors' responsibility for fraud detection”. Journal of Accountancy, Vol. 1, pp. 28-36, 2003.

[27] Moten Jr, J., Fitterer, A., Brazier, E., Leonard, J., \& Brown, A.: "Examining online college cyber cheating methods and prevention measures". Electronic Journal of Elearning, Vol. 11, No. 2, pp. 139-146, 2013.

[28] Simkin, M. G., \& McLeod, A.: "Why do college students cheat?", Journal of Business Ethics, Vol. 94, No. 3, pp. 441-453, 2010.

[29] Christe, B.: "Designing online courses to discourage dishonesty". Educause Quarterly, Vol. 26, No. 4, pp. 54-58, 2003.

[30] Owunwanne, D., Rustagi, N., \& Dada, R.: "Students perceptions of cheating and plagiarism in higher institutions". Journal of College Teaching \& Learning (TLC), Vol. 7, No. 11, pp. 59-68, 2010.

[31] Carpenter, D. D., Harding, T. S., Finelli, C. J., Montgomery, S. M., \& Passow, H. J.: "Engineering students' perceptions of and attitudes towards cheating". Journal of Engineering Education, Vol. 95, No. 3, pp. 181-194, 2006.

[32] Schneider, A.: "Why Professors Don't Do More To Stop Students Who Cheat". Chronicle of Higher Education, Vol. 45, No. 20, 1999.

[33] Jendrek, M. P.: "Faculty Reactions to Academic Dishonesty". Journal of College Student Development, Vol. 33, No. 3, pp. 260-273, 1989.

[34] Johnston, D. K.: "Cheating: limits of individual integrity". Journal of Moral Education, Vol. 25, No. 2, pp. 159-171, 1996.

[35] Howard, L. W., Tang, T. L.-P., \& Austin, M. J.: "Teaching critical thinking skills: Ability, motivation, intervention, and the Pygmalion effect". Journal of Business Ethics, Vol. 128, No. 1, pp. 133-147, 2015. 